\title{
Successional changes in bacterial community assemblages following anoxia in the hypolimnion of a eutrophic lake
}

\author{
Anne-Catherine Lehours ${ }^{1,2, *}$, Corinne Bardot ${ }^{1}$, Pierre-François Pelisson $^{1}$, \\ Annie Guedon ${ }^{1}$, Stephane Pesce ${ }^{1}$, Guy Demeure ${ }^{1}$, Denis Sargos ${ }^{1}$, Gérard Fonty ${ }^{1}$ \\ ${ }^{1}$ Laboratoire Microorganismes: Génome et Environnement (LMGE), Université Blaise Pascal-Clermont-Ferrand, \\ UMR CNRS 6023, 24 avenue des Landais, 63177 Aubière Cedex, France \\ ${ }^{2}$ Present address: Station Biologique de Roscoff, Place Georges Teissier, 29680 Roscoff, France
}

\begin{abstract}
Dynamics of bacterial assemblages following anoxia in the hypolimnion of a eutrophic lake (Lake Aydat) were characterized. The sampling started in spring before complete anoxia and was continued weekly until complete mixing of the water column occurred in autumn. Bacterial community patterns at 3 sampled depths $(10,12$ and $14 \mathrm{~m}$ ) were investigated using temporal temperature gradient gel electrophoresis (TTGE) and terminal restriction fragment length polymorphism (T-RFLP) analyses. Results revealed changes in the structure of the bacterial communities as conditions changed from oxic to anoxic. Once anoxia had been reached, anaerobic bacterial communities continued to change and exhibited gradual successional patterns at the 3 depths. During the anoxic period, bacterial communities at 10 and $12 \mathrm{~m}$ were split into 2 groups corresponding to the steps 'until' and 'after' maximum stratification, which occurred on 19 August 2004. While the succession of the bacterial community in the hypolimnion was dynamic and exhibited gradual patterns at the 3 depths, a 'sensitivity gradient' to $\mathrm{O}_{2}$ depletion was suggested: communities at $10 \mathrm{~m}$ appeared to be more affected by the shift in $\mathrm{O}_{2}$ concentrations than those in deeper water layers.
\end{abstract}

KEY WORDS: Lake $\cdot$ Bacterial community structure $\cdot$ Succession $\cdot$ Molecular fingerprint methods

\section{INTRODUCTION}

In the water column of many eutrophic aquatic systems, 3 steps are observed during thermal stratification in regard to $\mathrm{O}_{2}$ concentrations: (1) in spring, increasing solar radiation leads to vertical stratification, which reduces the rate of $\mathrm{O}_{2}$ supply while aerobic respiration removes $\mathrm{O}_{2}$ (2) in summer, the deepest water layers (hypolimnion) are anoxic; and (3) in autumn, decreasing solar radiation leads to cooling of surface waters and the deep penetration of $\mathrm{O}_{2}$. This overturn of $\mathrm{O}_{2}$ leads to the reoxygenation of the entire water column. Consequently, in the course of a few days, the microbial community habitat in the hypolimnion shifts from $\mathrm{O}_{2}$ supersaturation to anoxia (or the opposite), and new microbial niches are created, filled and destroyed in rapid succession (Finlay et al. 1997).

Lake Aydat in the French Massif Central supports an extensive seasonal anoxic zone (from 6 to $14 \mathrm{~m}$; Michard et al. 2001), which forms every year from May to October (Bettarel et al. 2004). This hypolimnion is populated with living and active communities of bacteria; bacterial abundance averages $5 \times 10^{6} \mathrm{cells} \mathrm{ml}^{-1}$ and bacterial production $\left(114.2 \times 10^{6}\right.$ bacteria $\left.\mathrm{l}^{-1} \mathrm{~h}^{-1}\right)$ is greater than that in overlying oxic water (Bettarel et al. 2003, 2004). In this anoxic and aphotic water layer, fish, zooplankton and phytoplankton are absent. Grazers such as ciliates and flagellates are rare and grazing rates are low (Bettarel et al. 2003, 2004), as typically noted in anoxic waters (Weinbauer \& Holfe 1998). 
Although changes in bacterial community composition are influenced by carbon and nutrient sources (i.e. bottom-up influences; e.g. Billen et al. 1990) and viral lyses (Weinbauer \& Holfe 1998, Bettarel et al. 2004), this anoxic zone is an accurate and simplified (with less complex trophic interactions) system in which to analyze the responses of bacterial populations to shifting environmental conditions (e.g. anoxia).

The objective of the present study was to monitor the dynamics of the dominant bacterial community members in the hypolimnion of the eutrophic Lake Aydat during the 3 periods of thermal stratification. In order to assess changes in the bacterial community, 2 cultivation-independent techniques were used on the $16 \mathrm{~S}$ rRNA gene: terminal restriction fragment length polymorphism (T-RFLP) and temporal temperature gradient gel electrophoresis (TTGE).

\section{MATERIALS AND METHODS}

Site description and sample collection. Lake Aydat, located at $2^{\circ} 59^{\prime} \mathrm{E}, 45^{\circ} 40^{\prime} \mathrm{N}$ at $825 \mathrm{~m}$ altitude in the French Massif Central, is a small (surface area $60.3 \mathrm{ha}$, maximum depth $14.5 \mathrm{~m}$ ) dimictic lake. It originates from a dam formed by a basaltic flow approximately 7500 yr ago.

Depth profiles of water temperature $\left( \pm 0.2^{\circ} \mathrm{C}\right)$ and $\mathrm{O}_{2}$ concentration $\left( \pm 0.03 \mathrm{mg} \mathrm{l}^{-1}\right)$ were determined in situ using a portable multisensor probe (WTW), and values were interpolated through the water column by using Surfer 7.0 (Golden Software). For 28 wk from May to November 2004, weekly sampling was performed at 10, 12 and $14 \mathrm{~m}$ water depth (see Figs. 1a, b) at the deepest place in the lake using an 81 horizontal Van Dorn bottle. The physicochemical composition of the hypolimnion has been reported in previous studies (e.g. Ogier 1999).

DNA extraction and PCR amplification. Water samples of $400 \mathrm{ml}$ were filtered onto $0.2 \mu \mathrm{m}$ pore-size polycarbonate filters (47 mm diameter, GTTP, Millipore). DNA extractions were performed as described in Jardillier et al. (2004). For T-RFLP analysis, amplification of the bacterial 16S rDNA genes was performed using a combination of the bacterial 5'-FAM-labeled $27 \mathrm{f}$ primer and the universal primer 1492r (Table 1). For TTGE analysis, the primer $27 \mathrm{f}$, modified with a guanine-cytosine-rich sequence at the $5^{\prime}$ end, was used in combination with the universal primer $518 \mathrm{r}$ (Table 1). The reaction mixture contained $5 \mu \mathrm{l} 10 \times$ buffer, $2 \mathrm{mM} \mathrm{MgCl}_{2}, 200 \mu \mathrm{M}$ of each deoxyribonu- cleotide triphosphate (dATP, dCTP, dGTP, dTTP; Eurobio), $1.25 \mathrm{U}$ of Taq polymerase (Bioline, Abcyss), 10 pmoles of each oligonucleotide primer and 50 to $100 \mathrm{ng}$ of template DNA, for a final volume of $50 \mu \mathrm{l}$. Amplifications were performed with a PTC-200 thermal cycler (MJ Research) using the following program: a 5 min hot start at $95^{\circ} \mathrm{C}$, followed by 30 cycles consisting of denaturation $\left(1 \mathrm{~min}\right.$ at $95^{\circ} \mathrm{C}$ for T-RFLP; $30 \mathrm{~s}$ at $94^{\circ} \mathrm{C}$ for TTGE), annealing $\left(1 \mathrm{~min}\right.$ at $55^{\circ} \mathrm{C}$ for T-RFLP; $30 \mathrm{~s}$ for TTGE) and extension $\left(1 \mathrm{~min}\right.$ at $72^{\circ} \mathrm{C}$ for $\mathrm{T}$ RFLP; $30 \mathrm{~s}$ for TTGE), with a final extension for $10 \mathrm{~min}$ at $72^{\circ} \mathrm{C}$ for T-RFLP and 7 min at $72^{\circ} \mathrm{C}$ for TTGE. Amplified DNA was checked by electrophoresis in $1.0 \%$ agarose in $1 \times$ Tris-Borate-EDTA (TBE) buffer.

T-RFLP procedure. Twenty-five $\mu \mathrm{l}$ of enzymatic digestion mixture containing $100 \mathrm{ng}$ of labeled DNA and $20 \mathrm{U}$ of MspI (Sigma) in the manufacturer's recommended reaction buffer were incubated for $12 \mathrm{~h}$ at $37^{\circ} \mathrm{C}$ (Lehours et al. 2005). Restriction digests were inactivated by heating to $65^{\circ} \mathrm{C}$ for $10 \mathrm{~min}$ and then purified and desalted using Micropure EZ-Microcon 30 columns (Millipore) to prevent ion interference with the uptake of DNA using electrokinetic injection (Moeseneder et al. 1999). The volume of all samples was checked after EZ column purification in order to reduce bias resulting from differences in column eluent volume, which could lead to large differences in mass loaded into the sequencer and, consequently, to large differences observed in detectable peaks (Lehours et al. 2005). Fluorescently labeled terminal restriction fragments (TRFs) were analyzed on an ABI 3700 automated sequence analyzer (Applied Biosystems) in GeneScan mode. We then mixed $2.3 \mu \mathrm{l}$ of the restriction enzyme digest with $0.5 \mu$ of GeneScan-1000 ROX size standard (Applied Biosystems) and $3.2 \mu \mathrm{l}$ of deionized formamide, and then denaturated at $94^{\circ} \mathrm{C}$ for $3 \mathrm{~min}$. Injections were performed electrokinetically at $7.7 \mathrm{kV}$ for $40 \mathrm{~s}$. Three replicate TRF profiles were obtained from the digested DNA by loading 3 aliquots of digested DNA onto 3 different capillaries. This replication level was performed to measure the degree of variation in TRF profiles arising solely as a result of experimental error during electrophoresis of DNA digest samples. To avoid detection of primers and 
uncertainties in size determination, TRFs smaller than $50 \mathrm{bp}$ and larger than $800 \mathrm{bp}$ were excluded. TRFs were analyzed by aligning fragments to the size standard by using GeneScan analytical software (Applied Biosystems). Replicate profiles of each sample were compared to identify the reproducible fragments (peaks that appeared in at least 2 replicate profiles of a sample). Only reproducible TRFs were considered in the numerical analysis. TRFs that differed by less than 1 bp were considered identical (Dunbar et al. 2001) and were clustered. A program in Visual Basic for Excel was developed to automate these procedures. The TRF signal (representing height or area) was assumed to be proportional to the relative abundance of the species. TRFs were expressed as relative abundances of the total signal detected in the T-RFLP profile. TRFs below a threshold of $0.1 \%$ of the total profile signal were deleted and relative abundances of remaining TRFs were recalculated (Blackwood et al. 2007).

TTGE procedure. Three hundred ng of each amplified product were electrophoresed along an $8 \%$ (w/v) polyacrylamide gel (7 M urea, 1.25× Tris-acetateEDTA [TAE] buffer, $0.06 \%$ Temed and $0.06 \%$ ammonium persulfate) using the DCode Universal Mutation Detection System (Bio-Rad). Runs were performed in $1.25 \times \mathrm{TAE}$ buffer at $68 \mathrm{~V}$ for $17 \mathrm{~h}$ with a temperature range of 66 to $69.6^{\circ} \mathrm{C}$ and a ramp rate of $0.2^{\circ} \mathrm{C} \mathrm{h}^{-1}$. The reference patterns consisted of a mixture of amplified 16S rDNA V1 to V3 fragments of 3 bacterial strains: Aeromonas caviae, Kurthia zopfii and Escherichia coli. Following electrophoresis, gels were stained in a Gel Star nucleic acid gel stain bath (BMA) and the banding patterns were examined under ultraviolet light. The gels were digitally photographed (Versa Doc Imaging System, Bio-Rad), converted to TIFF files, normalized using reference patterns and analyzed with GelCompare 4.6 (Applied Maths).

Analyses of T-RFLP and TTGE patterns. From the binary data, dissimilarities among the T-RFLP and TTGE patterns were estimated using Dice's coefficient: $\mathrm{D}=1-\left[\left(2 \mathrm{~N}_{\mathrm{ab}}\right) /\left(2 \mathrm{~N}_{\mathrm{ab}}+\mathrm{N}_{\mathrm{a}}+\mathrm{N}_{\mathrm{b}}\right)\right]$, where $\mathrm{N}_{\mathrm{ab}}$ is the number of bands or TRFs that are present in samples a and $b_{;} N_{a}$ is the number of bands or TRFs present in $a_{\text {; }}$ and $\mathrm{N}_{\mathrm{b}}$ is the number of bands or TRFs present in $\mathrm{b}$ (Sneath \& Sokal 1973). For the T-RFLP pattern, dendrograms were generated from the above matrix using Ward's method, which uses an ANOVA approach to evaluate the distances between clusters (Ward 1963). A distance of 1.1 was used to separate clusters in hierarchical classification performed from T-RFLP data. Analysis of similarity (ANOSIM; Clarke 1993) was used to test the hypothesis that communities within clusters were more similar to each other than to communities in others clusters. Correlations between
T-RFLP and TTGE dissimilarity matrices were calculated using a Mantel test (Mantel 1967) with 10000 permutations, performed with XLSTAT version 6.01 (Addinsoft). Similarity between T-RFLP patterns was calculated using correspondence analysis (CA), computed using the R software ADE4 package (cran.r-project. org/). CAs for TTGE data were performed with XLSTAT. Canonical correspondence analyses (CCAs) (Legendre \& Legendre 1998) were used to determine the extent to which dissolved oxygen concentrations explained patterns of similarity within bacterial communities, and were performed with PAST 1.81 (Hammer et al. 2001). The Smith \& Wilson evenness index (Smith \& Wilson 1996) was calculated as previously described from T-RFLP data using the Ecological Evenness Calculator software (www.nateko.lu.se/personal/benjamin.smith/software). The number of distinct TRFs in a sample was expressed as richness (S).

\section{RESULTS}

\section{Spatiotemporal profiles of dissolved $\mathrm{O}_{2}$ and temperature}

The changes in water temperature and $\mathrm{O}_{2}$ contents were typical of a temperate lake, with stratification starting in spring (Fig. 1). Anoxia started to occur in deeper water in May (27 May 2004 at 14 m, T3; Fig. 1A) and progressively ascended the water column until reaching a depth of $6 \mathrm{~m}$ at the maximum of stratification (19 August 2004, T15; Fig. 1A). By mid-October, a deep penetration of $\mathrm{O}_{2}$ was observed (Fig. 1A). Following the overturn (18 November 2004, T28; Fig. 1), $\mathrm{O}_{2}$ occurred throughout the entire water column.

During the sampling effort, several different periods were observed with regard to dissolved $\mathrm{O}_{2}$ concentrations at the 3 sampled depths (Figs. 2A to 4A): oxic, hypoxic, anoxic and re-oxidized periods (Table 2). Considering the temperature and $\mathrm{O}_{2}$ diagrams (Fig. 1), 2 stages were distinguished during anoxia: 'until' maximum stratification and 'after' maximum stratification (Table 2).

\section{Dynamics of bacterioplankton communities}

Hierarchical cluster analyses were performed at each depth from T-RFLP binary data and results are presented in Figs. 2C \& 4C. At 10 m, T-RFLP data were clustered into 5 groups considering a cut-off value of 1.1: cluster C1 grouped bacterial communities at dates $\mathrm{T} 1$ and T2, for which the highest concentrations of dissolved $\mathrm{O}_{2}$ were measured (up to $7 \mathrm{mg} \mathrm{ml}^{-1}$, Fig. 2A); cluster $\mathrm{C} 2$ grouped communities of the aerobic and 


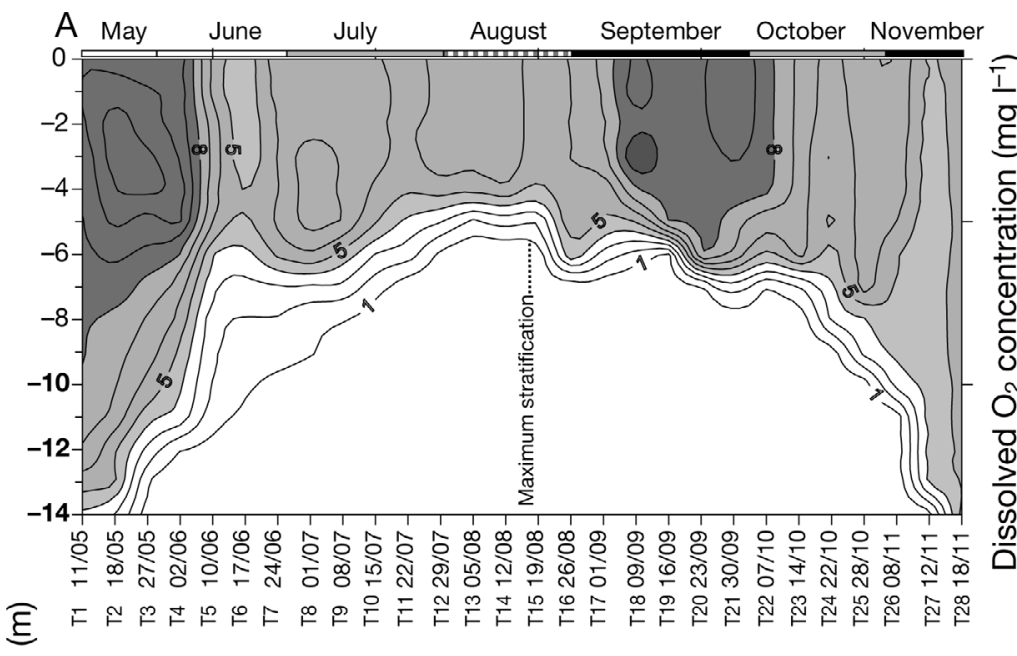

communities of: the aerobic and hypoxic periods ( $\mathrm{T} 1$ to $\mathrm{T} 2$ ), the beginning of anoxia (T3 to T9), the end of anoxia (T26 to $\mathrm{T} 27$ ) and the re-oxidized conditions (T28) (Fig. 4C). These cluster analyses from T-RFLP data were confirmed with ANOSIM, which showed that communities in each cluster were more similar to each other than to those of the other clusters (Table 3).

Similarities between TTGE patterns are illustrated by correspondence analyses (Fig. 5). At 10 m, groupings were very similar to those obtained by T-RFLP data: groups G1 and G4 grouped communities of the aerobic period before and after anoxia, respectively. At $12 \mathrm{~m}$, more similarity was noted between communities at T28 and communities of the aerobic and hypoxic periods (T1 to T5) such as observed from T-RFLP data (Fig. 3C). At $14 \mathrm{~m}$, group G1 clustered communities from $\mathrm{T} 1$ to $\mathrm{T} 11$, but not communities at T27, as noted from T-RFLP data (Fig. 4C). Despite some differences between T-RFLP and TTGE analyses, which were more pronounced at $14 \mathrm{~m}$, significant correlations between T-RFLP and TTGE dissimilarity matrices were found at the 3 sampled depths $(r=0.638$ at $10 \mathrm{~m}, \mathrm{r}=0.683$ at $12 \mathrm{~m}, \mathrm{r}=0.473$ at $14 \mathrm{~m}, \mathrm{p}=0.0001$ ).

In the CA analysis performed from $\mathrm{T}$ RFLP patterns, bacterial communities at 12 and $14 \mathrm{~m}$ shifted away from those at $10 \mathrm{~m}$, but as the anoxia progressed, similarities between communities at the 3 depths increased (Fig. 6). More similarities were observed between the later

hypoxic periods (Fig. 2C); communities of the anoxic period were clustered into $\mathrm{C} 3$ and $\mathrm{C} 4$ according to the 2 aforementioned stages ('until' and 'after' maximum stratification, Table 2); and cluster C5 grouped the bacterial communities of the re-oxidized period. At 12 and $14 \mathrm{~m}, 3$ clusters were discriminated (Figs. 3C \& 4C). At $12 \mathrm{~m}$, cluster $\mathrm{C} 1$ grouped together communities of the aerobic and hypoxic periods (T1 to T5) with those of the re-oxidized period (T27 to T28), and clusters C2 and C3 grouped together the communities of the anoxic 'until' and 'after' maximum stratification periods, respectively. Note that, at 10 and $12 \mathrm{~m}$, more dissimilarity was observed between bacterial communities of the 2 anoxic stages than between communities of the oxic and anoxic periods. At $14 \mathrm{~m}$, a more distinct pattern was observed. Cluster C1 grouped together sampling dates at $10 \mathrm{~m}$ (T24 to T28) and the early and intermediate sampling dates at 14 and $12 \mathrm{~m}$ (Fig. 6). As observed from cluster analyses (Figs. 3C \& 4C), more similarities were noted between the communities of the oxic period and those of the re-oxidized conditions at 12 and $14 \mathrm{~m}$.

CCA performed from relative abundance TRF data revealed that more than $30 \%$ of the variability of the bacterial community at 10,12 and $14 \mathrm{~m}$ was described by dissolved $\mathrm{O}_{2}$ and temperature variables (A.-C. Lehours et al. unpubl. data). At each depth, the distribution of the aerobic, hypoxic and anoxic ('until' and 'after' maximum stratification) communities was a response to the dissolved $\mathrm{O}_{2}$ gradient, with communities of oxic and hypoxic period discriminated on Axis 1 from communities of the anoxic period (Fig. 7). $\mathrm{O}_{2}$ con- 

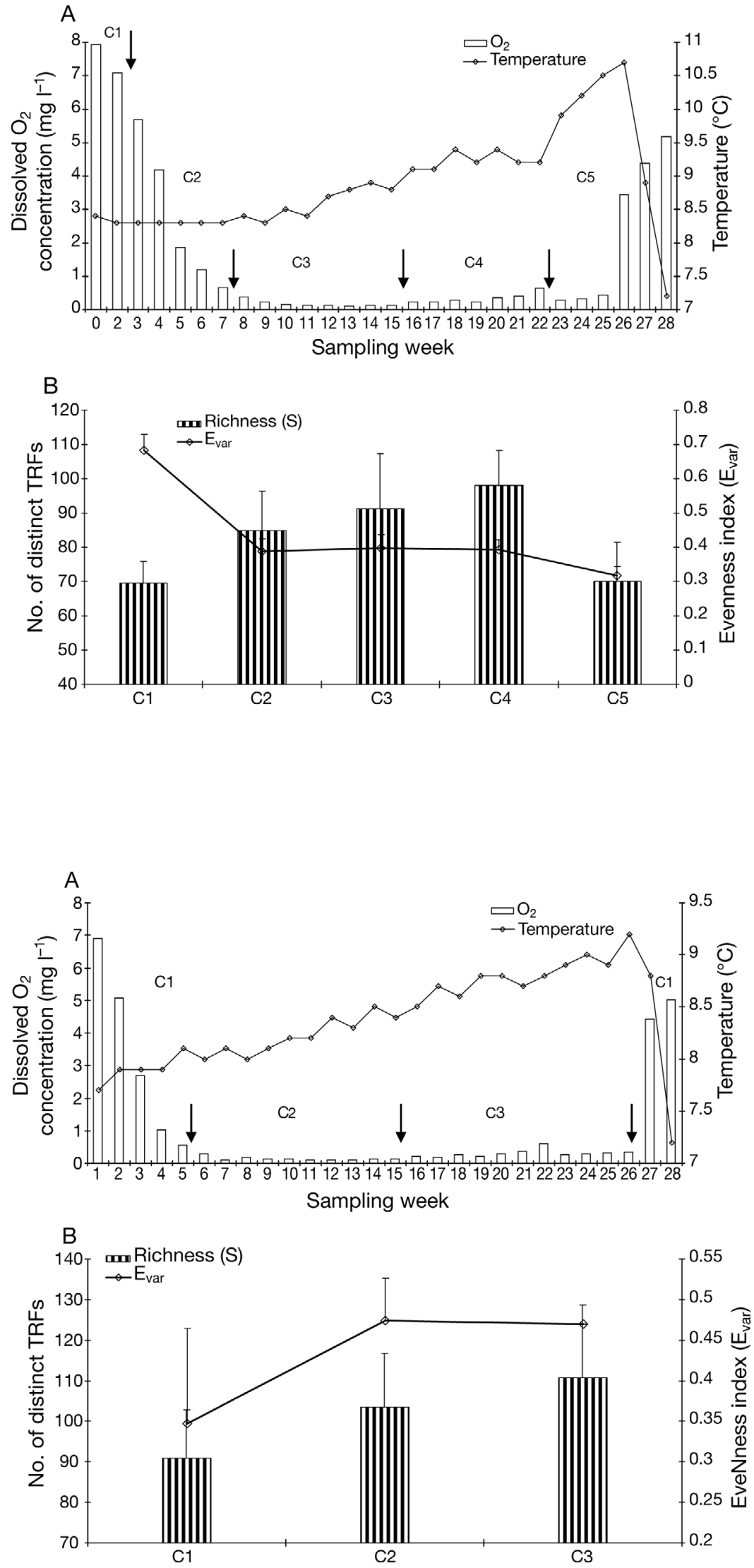

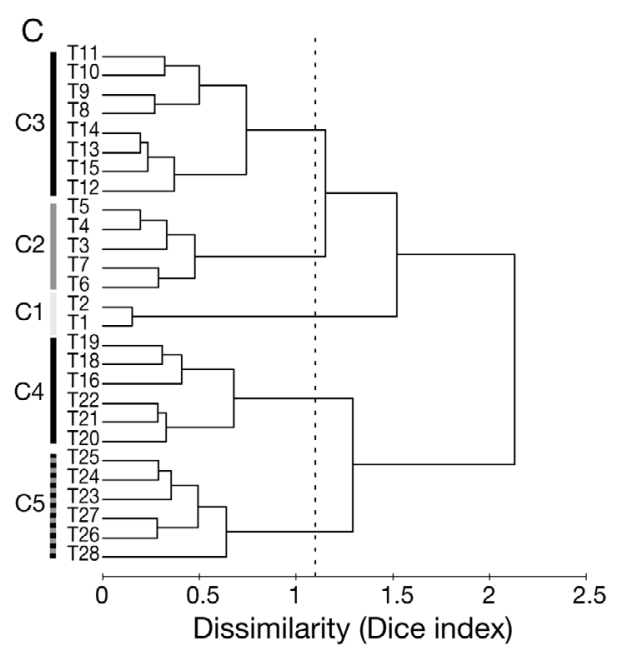

Fig. 2. (A) Development of dissolved $\mathrm{O}_{2}$ concentrations $\left(\mathrm{mg} \mathrm{l}^{-1}\right)$ and temperature $\left({ }^{\circ} \mathrm{C}\right)$ at $10 \mathrm{~m}$. (B) Development of the average richness (S) and Smith \& Wilson evenness index $\left(\mathrm{E}_{\mathrm{var}}\right)$ for clusters defined at $10 \mathrm{~m}$. (C) Clusters defined by hierarchical analysis performed from community T-RFLP fingerprints at $10 \mathrm{~m}$

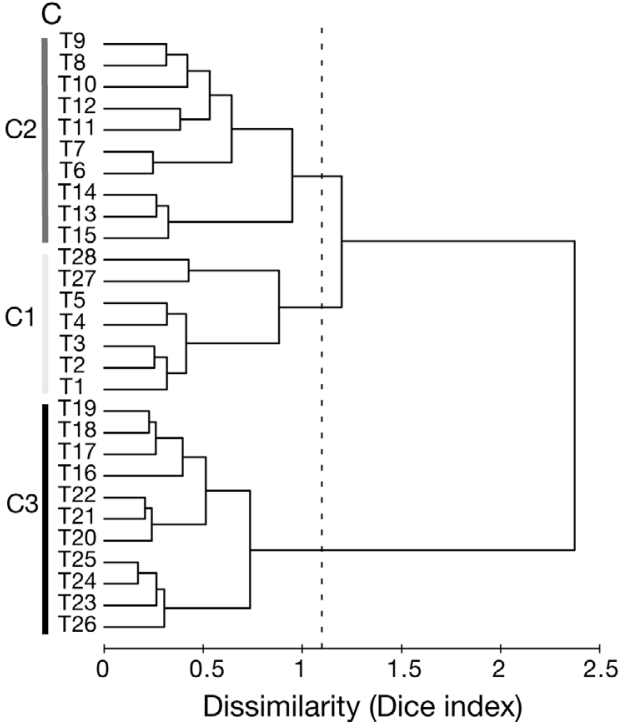

Fig. 3. (A) Development of dissolved $\mathrm{O}_{2}$ concentrations $\left(\mathrm{mg} \mathrm{l}^{-1}\right)$ and temperature $\left({ }^{\circ} \mathrm{C}\right)$ at $12 \mathrm{~m}$ depth. (B) Development of the average richness (S) and Smith \& Wilson evenness index $\left(\mathrm{E}_{\mathrm{var}}\right)$ for clusters defined at $12 \mathrm{~m}$. (C) Clusters defined by hierarchical analysis performed from community T-RFLP fingerprint at $12 \mathrm{~m}$ 

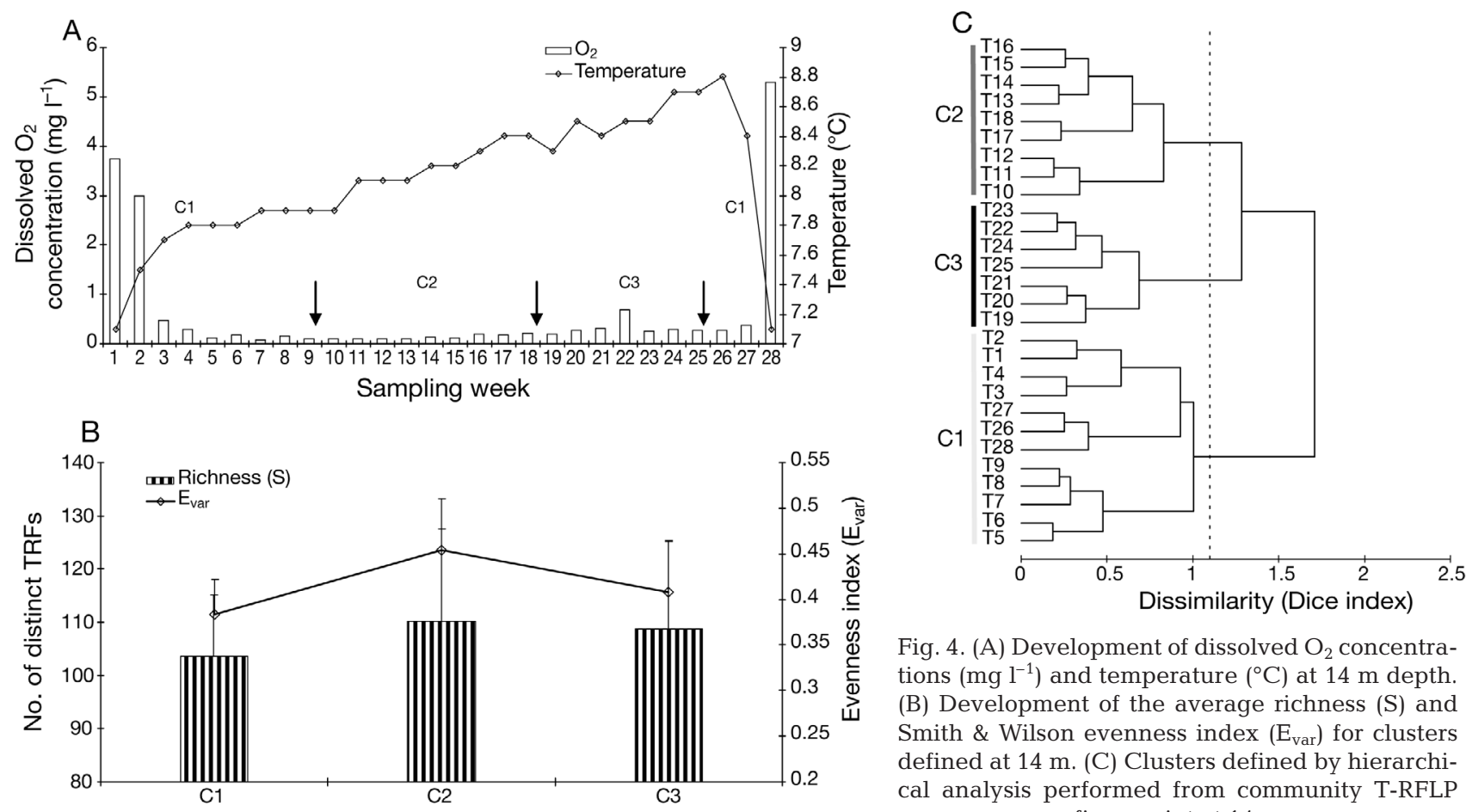

Fig. 4. (A) Development of dissolved $\mathrm{O}_{2}$ concentrations $\left(\mathrm{mg} \mathrm{l}^{-1}\right)$ and temperature $\left({ }^{\circ} \mathrm{C}\right)$ at $14 \mathrm{~m}$ depth. (B) Development of the average richness (S) and Smith \& Wilson evenness index $\left(\mathrm{E}_{\mathrm{var}}\right)$ for clusters defined at $14 \mathrm{~m}$. (C) Clusters defined by hierarchical analysis performed from community T-RFLP fingerprint at $14 \mathrm{~m}$

Table 2. Steps observed at the 3 sampled depths in regard to $\mathrm{O}_{2}$ concentrations during the sampling effort. T1 to T28: weekly sampling dates from 11 May 2004 (T1) to 18 November 2004 (T28)

\begin{tabular}{|c|c|c|c|c|c|}
\hline \multirow{3}{*}{ State } & \multirow{2}{*}{\multicolumn{2}{|c|}{ Before anoxia }} & \multirow{2}{*}{\multicolumn{2}{|c|}{$\begin{array}{l}\text { - Sampling period } \\
\quad \text { Anoxia }\left(<0.75 \mathrm{mg} \mathrm{l}^{-1}\right) \\
\end{array}$}} & \multirow{3}{*}{$\begin{array}{l}\text { After anoxia } \\
\text { Aerobic period }\end{array}$} \\
\hline & & & & & \\
\hline & Aerobic period & $\begin{array}{l}\text { Hypoxic period } \\
\left(<3 \mathrm{mg} \mathrm{l}^{-1}\right)\end{array}$ & $\begin{array}{l}\text { Until maximum } \\
\text { stratification }\end{array}$ & $\begin{array}{l}\text { After maximum } \\
\text { stratification }\end{array}$ & \\
\hline $10 \mathrm{~m}$ & $\mathrm{~T} 1 \rightarrow \mathrm{T} 4$ & $\mathrm{~T} 5 \rightarrow \mathrm{T} 7$ & $\mathrm{~T} 8 \rightarrow \mathrm{T} 15$ & $\mathrm{~T} 16 \rightarrow \mathrm{T} 25$ & $\mathrm{~T} 26 \rightarrow \mathrm{T} 28$ \\
\hline $12 \mathrm{~m}$ & $\mathrm{~T} 1 \rightarrow \mathrm{T} 2$ & $\mathrm{~T} 3 \rightarrow \mathrm{T} 5$ & $\mathrm{~T} 6 \rightarrow \mathrm{T} 15$ & $\mathrm{~T} 16 \rightarrow \mathrm{T} 26$ & $\mathrm{~T} 27 \rightarrow \mathrm{T} 28$ \\
\hline $14 \mathrm{~m}$ & $\mathrm{~T} 1$ & $\mathrm{~T} 2$ & $\mathrm{~T} 3 \rightarrow \mathrm{T} 17$ & $\mathrm{~T} 18 \rightarrow \mathrm{T} 27$ & T28 \\
\hline
\end{tabular}

Table 3. ANOSIM statistics for comparisons of communities between clusters C1 to C5 (for a cut-off value of 1.1) using T-RFLP similarity values derived from binary data (presence/absence). -: no data

\begin{tabular}{|c|c|c|c|c|c|c|}
\hline \multirow[b]{2}{*}{ Comparison } & \multicolumn{2}{|c|}{$10 \mathrm{~m}$} & \multicolumn{2}{|c|}{ Sampling depth } & \multirow[b]{2}{*}{$\mathrm{R}$} & \multirow[b]{2}{*}{$\mathrm{p}$} \\
\hline & $\mathrm{R}$ & $\mathrm{p}$ & $\mathrm{R}$ & $\mathrm{p}$ & & \\
\hline C1 vs. C2 & 1 & 0.04 & 0.53 & 0.0001 & 0.49 & 0.0001 \\
\hline C1 vs. C3 & 1 & 0.02 & 0.92 & 0.0001 & 0.47 & 0.0001 \\
\hline C1 vs. C4 & 1 & 0.02 & - & - & - & - \\
\hline C1 vs. C5 & 1 & 0.05 & - & - & - & - \\
\hline C2 vs. C3 & 0.83 & 0.0004 & 0.80 & 0.0001 & 0.47 & 0.0002 \\
\hline C2 vs. C4 & 0.93 & 0.0013 & - & - & - & - \\
\hline C2 vs. C5 & 0.99 & 0.008 & - & - & - & - \\
\hline C3 vs. C4 & 0.80 & 0.0001 & - & - & - & - \\
\hline C3 vs. C5 & 1 & 0.0008 & - & - & - & - \\
\hline C4 vs. C5 & 0.69 & 0.0005 & - & - & - & - \\
\hline
\end{tabular}


centrations explained 41,22 and $14 \%$ of the community changes at $10 \mathrm{~m}, 12$ and $14 \mathrm{~m}$, respectively (Fig. 7). At $10 \mathrm{~m}$, communities at T23 to T27 were also clearly discriminated by temperature on axis 2 and directly corresponded to an increase in temperature (from 9.2 at T23 to $10.7^{\circ} \mathrm{C}$ at T27, Fig. 2A).
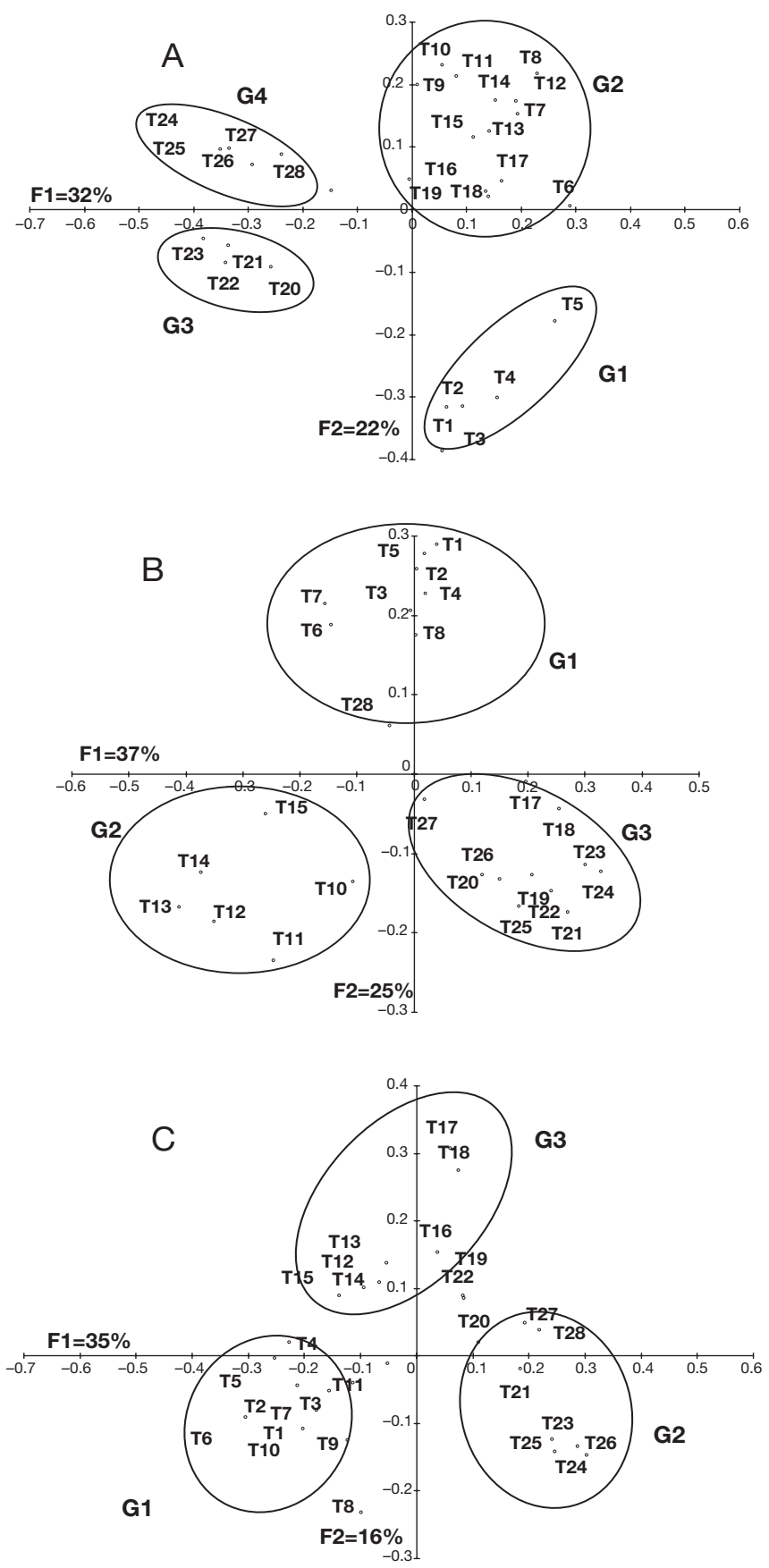

Fig. 5. Correspondence analyses (CA) performed with TTGE similarity values derived from binary data at (A) $10 \mathrm{~m}$, (B) $12 \mathrm{~m}$ and (C) $14 \mathrm{~m}$. T1 to T28: weekly sampling dates from 11 May 2004 (T1) to 18 November 2004 (T28); G1 to G4: groupings defined by CA

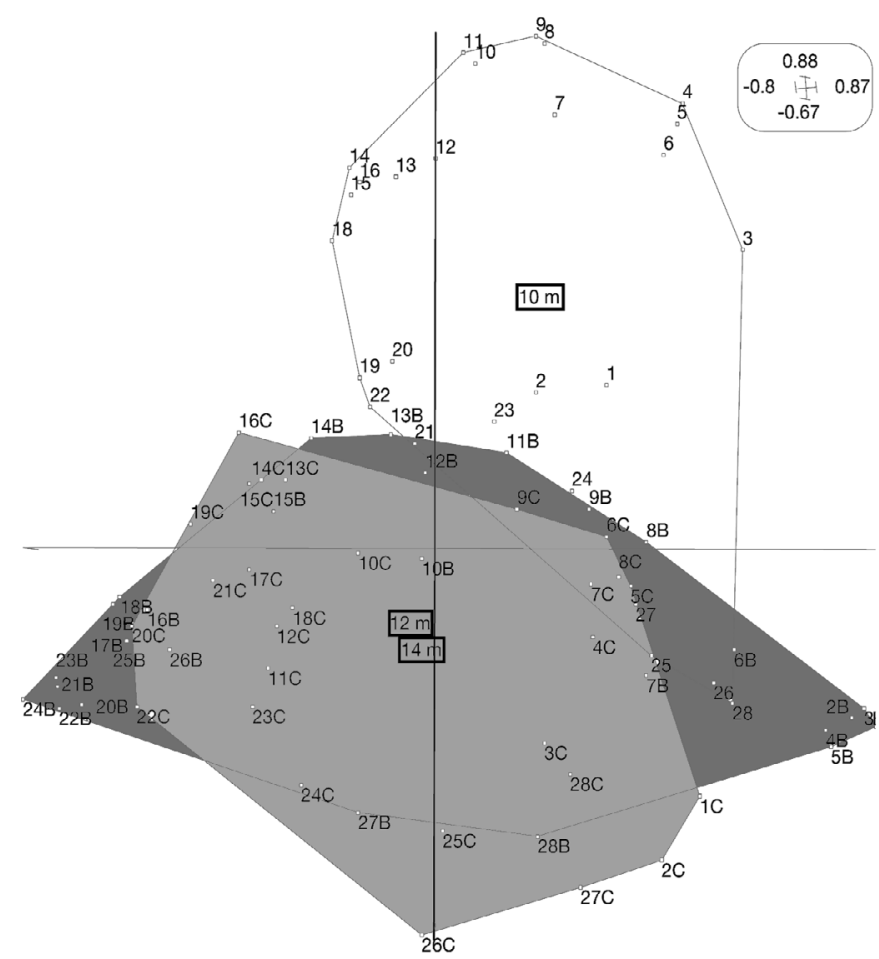

Fig. 6. Similarity among T-RFLP patterns illustrated by a correspondence analysis. Numbers alone correspond to dates at $10 \mathrm{~m}$; numbers followed by $\mathrm{B}$ correspond to dates at $12 \mathrm{~m}$; numbers followed by $\mathrm{C}$ correspond to dates at $14 \mathrm{~m}$. Dates at (unfilled polygon) $10 \mathrm{~m}$, (dark grey polygon) $12 \mathrm{~m}$ and (light grey polygon) $14 \mathrm{~m}$, respectively. The scale of the 2-dimensional plot is indicated at the top

\section{Diversity of bacterial communities}

The average values of the Smith \& Wilson evenness index $\left(\mathrm{E}_{\mathrm{var}}\right.$, Figs. 2B \& 4B) calculated at each depth were not significantly different between clusters defined from T-RFLP analyses (Figs. 2C \& 4C). Nevertheless, we observed that the maximum values of $E_{v a r}$ at 12 and $14 \mathrm{~m}$ occured for cluster $\mathrm{C} 2$, which grouped anoxic communities until maximum stratification $(0.47$ \pm 0.05 at $12 \mathrm{~m}, 0.45 \pm 0.05$ at $14 \mathrm{~m}$ ). Richness (S) was calculated from the number of different TRFs in each sample and was significantly correlated with $\mathrm{E}_{\mathrm{var}}$ at the 3 depths $(r=0.736, r=0.582, r=0.837, p<0.0001$ at 10 , 12 and $14 \mathrm{~m}$, respectively). For the 3 depths, the lowest $\mathrm{S}$ values were noted for communities of the aerobic period $\left(10 \mathrm{~m}: \mathrm{S}_{\mathrm{C} 1}=70 \pm 5, \mathrm{~S}_{\mathrm{C} 5}=70 \pm 11 ; 12 \mathrm{~m}: \mathrm{S}_{\mathrm{C} 1}=90\right.$ $\left.\pm 12 ; 14 \mathrm{~m}: \mathrm{S}_{\mathrm{C} 1}=103 \pm 11\right)$.

\section{DISCUSSION}

Several studies have gathered routine profiles of the transition from oxic to anoxic bacterial communities 

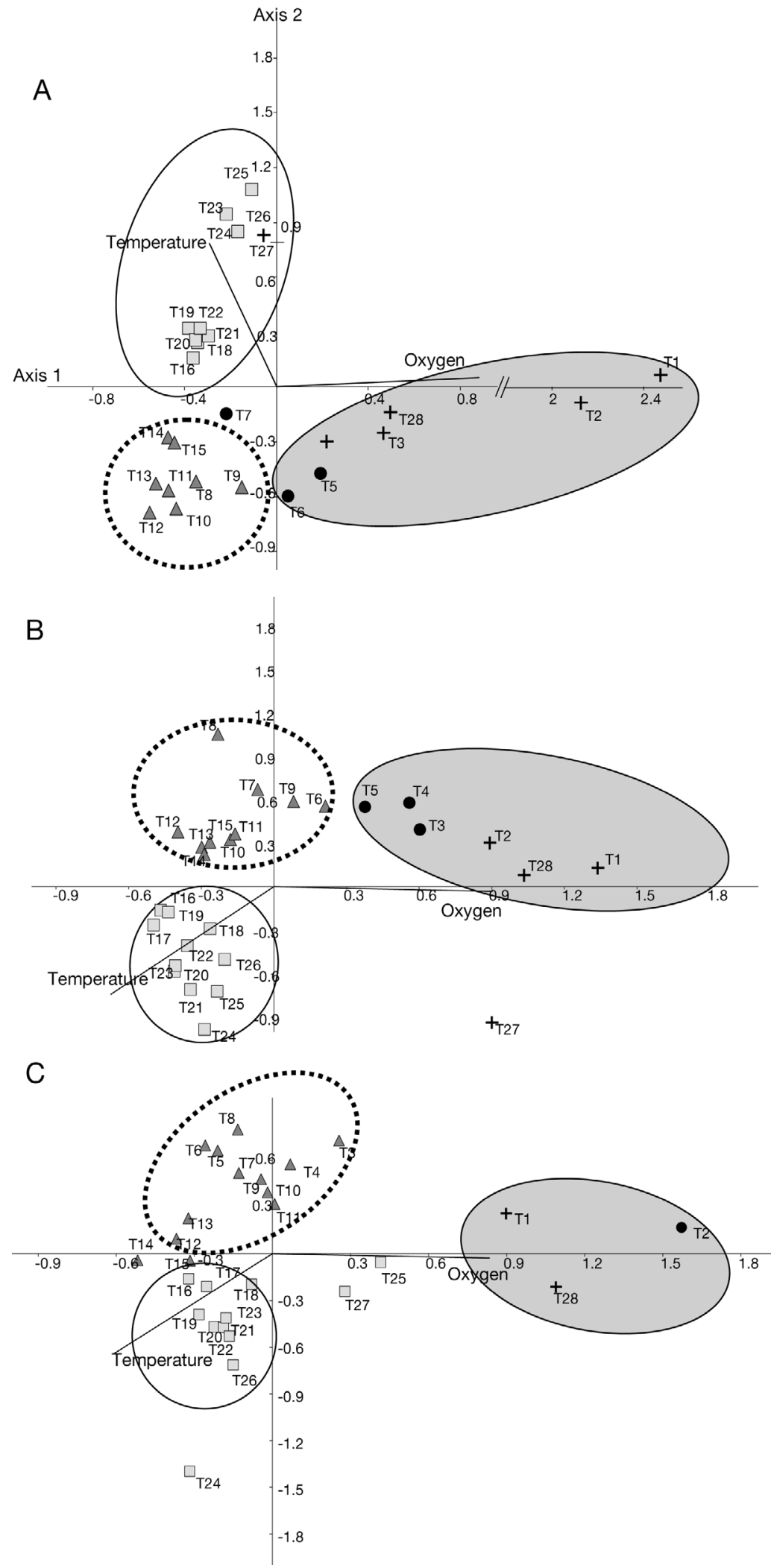

Fig. 7. Canonical correspondence analyses (CCA) performed using relative peak height of TRFs at (A) $10 \mathrm{~m}$, (B) $12 \mathrm{~m}$ and (C) $14 \mathrm{~m}$. Communities of the $(+)$ oxic, $(\bullet)$ hypoxic, $(\triangle)$ anoxic 'until' maximum stratification and $(\square)$ anoxic 'after' maximum stratification periods along a persistent vertical $\mathrm{O}_{2}$ gradient and in a permanent anoxic layer (e.g. Vetriani et al. 2003, Lüdemann et al. 2000, Lehours et al. 2005). However, to our knowledge, few studies have investigated the influence of anoxia on bacterial community structure and dynamics in the hypolimnion of a temporally stratified aquatic system. The dataset of the present study included 96 samples which were analyzed independently with 2 profiling procedures (T-RFLP and TTGE). Although these fingerprint techniques do not provide information on the functioning of bacterial communities, they are well suited to the investigation of changes in community structure over space and time. The sampling effort, performed weekly at 3 depths in the hypolimnion $(10,12$ and $14 \mathrm{~m})$, allowed us to investigate changes in bacterial structure following a time-lag in both the establishment of anoxic and re-oxidized conditions (Table 2, Fig. 1A).

\section{Methodological aspects and constraints}

The application of molecular methods for the description of the complexity of natural prokaryotic communities is hampered by methodological constraints; for example, more than $90 \%$ of bacteria have not yet been cultivated (Pace 1997). Whereas detailed phylogenetic information on the dominant members of microbial communities can be generated by sequencing cloned PCR products, the effort and cost involved hinders the analysis of multiple samples (Osborn et al. 2000). Rapid profiling procedures have gained in popularity when addressing questions related to the diversity, structural composition and dynamics of microbial communities (e.g. Muyzer et al. 1993, Lee et al. 1996). These methods present all the limitations common to molecular tools, including extraction of nucleic acids, biases and artifacts associated with enzymatic amplification of the nucleic acids, which have been well described in numerous publications (e.g. Head et al. 1998). We also assume that both TTGE and T-RFLP present their own pitfalls which can bias the estimation of bacterial diversity. For example, the number of TRFs observed 
can be biased by the formation of pseudo-TRFs (Egert \& Friedrich 2003) and by fragments of the same size originating from different taxa (Blackwood et al. 2007). The co-migrating events that occur in TTGE analysis may also lead to an underestimation of bacterial diversity (Muyzer \& Smalla 1998). Additionally, molecular profiling methods such as TTGE and T-RFLP normally characterize only dominant organisms (e.g. $>1 \%$ of the community) due to their detection limits (Blackwood et al. 2007). Hence, rare species, which often make up the vast majority of the diversity in microbial communities, are usually not detected (Pedrós-Alió 2006).

Considering that each enzyme presents a different level of success (fidelity) in detecting sequence variants from communities with varying richness, we selected MspI for the restriction digests, which has been shown to have increased resolving capacities (Engebretson \& Moyer 2003). A previous study also revealed that consistent richness and diversity dynamics were observed in an anoxic layer with 3 independent restriction digests (MspI, HhaI and RsaI), but that MspI was the top performer in terms of the ability to identify the greatest number of TRFs (Lehours et al. 2005). The inclusion of an internal size standard in each sample in T-RFLP should provide the necessary degree of reproducibility (Osborn et al. 2000) and thus enable integrative comparison of all samples (represented by a CA, Fig. 6). The semi-quantitative T-RFLP analysis procedure again contains several sources of potential bias, but does enable a more objective comparison of fingerprint patterns than TTGE because of the automated quantification of the relative abundance of individual TRFs (Lüdemann et al. 2000). To give more relevance to the present study, the bacterial communities were also investigated by a second profiling procedure (TTGE). Both methods led to similar observations about the changes in bacterial community such as revealed by the significant correlations between TTGE and T-RFLP similarity matrices. T-RFLP and TTGE clustering (TTGE clusters not shown) were consistent, despite the fact that different primers (Table 1) were used that targeted different (but likely overlapping) portions of the 16S rRNA gene. Results suggest that shifts and patterns observed were mainly the result of changes in bacterial community structure in the hypolimnion of Lake Aydat and not of artifacts associated with the methods used.

\section{Evenness and richness of bacterial communities}

Following the conclusions of Blackwood et al. (2007), the Smith \& Wilson evenness index $\left(\mathrm{E}_{\mathrm{var}}\right)$ was used in the present study as a measure of diversity. At 12 and $14 \mathrm{~m}, \mathrm{E}_{\mathrm{var}}$ tended to increase from aerobic to anaerobic conditions, suggesting that the diversity of anaerobic communities is at least comparable to (if not higher than) that of aerobic communities; thus, changes in bacterial community composition were not the result of a strong decrease in bacterial evenness. While the number of TRFs (richness, S) has not been previously found to accurately predict the number of taxa in microbial communities (Loisel et al. 2006, Blackwood et al. 2007), S-values are of interest because significant correlations between $\mathrm{S}$ and $\mathrm{E}_{\mathrm{var}}$ at the 3 depths were noted. An increase of mean $( \pm \mathrm{SD}) \mathrm{S}$ with depth $(10 \mathrm{~m}$ : $85 \pm 14 ; 12 \mathrm{~m}: 103 \pm 15 ; 14 \mathrm{~m}: 106 \pm 17$ ) was noted, suggesting that bacterial richness increased with depth in this freshwater anoxic zone as previously observed (Lehours et al. 2005).

\section{Temporal changes in community structure}

Changing environmental factors, localized gradients, stochastic processes, spatial separation and other factors could all result in random or loosely coordinated populations (Zhou et al. 2002, Martiny et al. 2003). However, during the thermal stratification of Lake Aydat, gradual successional patterns were observed at the 3 sampled depths (Figs. 2C, 3C, 4C \& 6).

\section{Shift from oxic to anoxic conditions}

At 10 and $12 \mathrm{~m}$, the initial consumption of $\mathrm{O}_{2}$ by aerobic bacteria led to a separation of aerobic from anaerobic processes, and as a result, to a temporal shift in the microbial community composition such as previously observed (Risatti et al. 1994, Brune et al. 2000). Changes in both TTGE and T-RFLP community patterns directly corresponded to the depletion of $\mathrm{O}_{2}$ (Figs. 2C \& 3C). This close correlation provides strong evidence that the presence or absence of $\mathrm{O}_{2}$ was a major factor in determining the changes in the bacterial community structure; this was also noted by Lüdemann et al. (2000) along a vertical $\mathrm{O}_{2}$ gradient in flooded paddy soil cores. The impact of $\mathrm{O}_{2}$ depletion on bacterial community composition was also confirmed by CCAs, which showed that oxic and anoxic communities were clearly determined by $\mathrm{O}_{2}$ at 10 and $12 \mathrm{~m}$ and, to a lesser extent, at $14 \mathrm{~m}$ (Fig. 7).

\section{Anoxic period}

During anoxia, succession of bacterial communities from both T-RFLP and TTGE patterns continued and followed an orderly progression (Figs. 2C, 3C, 4C \& 5). At 10 and $12 \mathrm{~m}$ during the anoxic period, the bacterial community became increasingly different from the 
oxic community over the following 15 wk of sampling (Figs. 2C \& 3C); this change corresponded to the date of maximum stratification (T15, Fig. 1). Crump et al. (2007) have also noted that the time available for the bacterial community composition to change depends on the amount of time that the water is anoxic. Bacterial communities within clusters 'until' (C3 at $10 \mathrm{~m}$ and $\mathrm{C} 2$ at $12 \mathrm{~m}$ ) and 'after' (C4 at $10 \mathrm{~m}$ and $\mathrm{C} 3$ at $12 \mathrm{~m}$ ) maximum stratification might be defined as 'early' and 'mature' anaerobic communities, respectively (Figs. 2C \& 3C). These groupings probably revealed the ability of organisms to respond to disturbance (e.g. opportunists and maintenance-type organisms; Sigler \& Zeyer 2004). However, we have to consider that many environmental factors may also contribute to these changes; for example, Crump et al. (2007) observed that a dramatic shift in bacterioplankton community composition in a stratified estuary occurred when sulfide concentrations were very high.

At $14 \mathrm{~m}$ in the present study, a special pattern was observed: after the onset of anoxia, community succession led to a mixture of aerobic and anaerobic populations (cluster C1, Fig. 4C), suggesting that some populations were able to live in both conditions (facultative anaerobic bacteria) or were maintained in anoxic micro-niches during the oxidized period. At $14 \mathrm{~m}$ depth (just above the sediment), low $\mathrm{O}_{2}$ concentrations are frequently present, such as observed from T1 to T2 $\left(\left[\mathrm{O}_{2}\right]<4 \mathrm{mg} \mathrm{l}^{-1}\right.$, Fig. 4A), raising the possibility that more communities were preadapted to anoxia. This may explain why aerobic communities clustered with those present at the onset of anoxia (T1 to T9). Similarities between bacterial communities from T25 to T28 (Figs. 4C \& 6) and those from T1 to T5 also suggest that communities at $14 \mathrm{~m}$ maintained their pioneer characteristics. This is consistent with Finlay et al. (1997), who suggested that microbial species that appeared during a period of stratification returned to the sediment, where they presumably remain viable. Therefore, in Lake Aydat, the sediment constitutes a reservoir of anaerobic bacteria which could quickly colonize the anoxic niches at $14 \mathrm{~m}$ once the environmental conditions become favorable.

\section{Renewal of $\mathrm{O}_{2}$}

In mid-October, $\mathrm{O}_{2}$ concentrations started to increase in the hypolimnion (Fig. 1A) and a shift in the bacterial community at $10 \mathrm{~m}$ was observed (clusters $\mathrm{C} 4$ and G4, Figs. 2C \& 5A). At 12 and $14 \mathrm{~m}$, communities of the re-oxidized conditions were similar to those of the aerobic period, as noted in the correspondence and clustering analyses (Figs. 3C, 4C \& 6). These results agree with the hypothesis that bacterial communities in the deepest water layers were adapted to these peri- odic changes in environmental conditions, and that low abundances of rare species were probably maintained throughout the stratification period.

\section{A sensitivity gradient to $\mathrm{O}_{2}$ depletion?}

Some observations suggest that bacterial communities in the hypolimnion of Lake Aydat exhibited different sensitivities to the shift in $\mathrm{O}_{2}$ concentrations: communities of the upper water layer $(10 \mathrm{~m})$ appeared to be more affected than those of the deeper water layers. For example, we noted that (1) bacterial communities of the aerobic periods 'before' and 'after' maximum stratification at $14 \mathrm{~m}$, and to a lesser extent at $12 \mathrm{~m}$, exhibited similarities (Figs. 3C \& 4C); (2) changes in both TTGE and T-RFLP community patterns at 10 and $12 \mathrm{~m}$ directly corresponded to the depletion of $\mathrm{O}_{2 i}$ (3) a mixture of aerobic and anaerobic populations were observed after the onset of anoxia at $14 \mathrm{~m}$ (cluster $\mathrm{C} 1$, Fig. 4C); and (4) CCA results revealed that $\mathrm{O}_{2}$ concentrations explained more variability in the community at $10 \mathrm{~m}$ than at 12 and $14 \mathrm{~m}$ (Fig. 7). Communities at $12 \mathrm{~m}$ may appear as intermediate communities: they were similar to those at $14 \mathrm{~m}$ (Fig. 6), but exhibited responses to $\mathrm{O}_{2}$ depletion similar to communities at $10 \mathrm{~m}$. From these observations, we hypothesize that a 'sensitivity gradient' to the shift in environmental conditions $\left(\mathrm{O}_{2}\right.$ depletion or re-oxidation) may exist between communities of the upper and deeper layers of the hypolimnion. This difference in community responses may be the result of native communities composed of persistent and well-adapted populations in the deepest water layers that may ensure the resilience of the systems after the periodic shift from oxic to anoxic conditions (or vice versa).

\section{CONCLUSION}

Succession of the bacterial community in the hypolimnion of Lake Aydat followed orderly and gradual patterns with 'cyclic' trajectories at 12 and $14 \mathrm{~m}$ (Figs. 3C, 4C \& 6). The hypolimnion of Lake Aydat is a dynamic system, periodically anoxic and subsequently refreshed with $\mathrm{O}_{2}$. Bacterioplankton communities in this hypolimnion are probably in a constant state of succession, shifting respiratory processes and phylogenetic composition as chemical conditions change over time, such as postulated by Crump et al. (2007). In addition, bacterioplankton communities in several systems have been shown to reassemble year after year (Crump \& Hobbie 2005, Fuhrman et al. 2006, Kan et al. 2006) suggesting that functional redundancy may be limited (Crump et al. 2007). 
Acknowledgements. We are greatful to S. Specel (Biogema Institute, Clermont-Ferrand), who supplied capillary electrophoresis for T-RFLP analysis. Many thanks also to J. C. Romagoux for his skilled technical assistance and to J. F. Humbert for his advice.

\section{LITERATURE CITED}

Bettarel Y, Sime-Ngando T, Amblard C, Carrias JF, Portelli C (2003) Virioplankton and microbial communities in aquatic systems: a seasonal study in two lakes of differing trophy. Freshw Biol 48:810-822

Bettarel Y, Sime-Ngando T, Amblard C, Dolan J (2004) Viral activity in two contrasting lake ecosystems. Appl Environ Microbiol 70:2941-2951

Billen G, Servais P, Becquevort S (1990) Dynamics of bacterioplankton in oligotrophic and eutrophic aquatic environments: Bottom-up or top-down control? Hydrobiologia 207:37-42

Blackwood CB, Hudleston D, Zak DR, Buyer JS (2007) Interpreting ecological diversity indices applied to terminal restriction fragment length polymorphism data: insights from simulated microbial communities. Appl Environ Microbiol 73:5276-5283

Brune A, Frenzel P, Cypionka H (2000) Life at the oxic-anoxic interface: microbial activities and adaptations. FEMS Microbiol Rev 24:691-710

Clarke KR (1993) Non-parametric multivariate analysis of changes in community structure. Aust J Ecol 8:117-143

Crump BC, Hobbie JE (2005) Synchrony and seasonality of bacterioplankton communities in two temperate rivers. Limnol Oceanogr 50:118-129

Crump BC, Peranteau C, Beckingham B, Cornwell JC (2007) Respiratory succession and community succession of bacterioplankton in seasonally anoxic estuarine waters. Appl Environ Microbiol 73:6802-6810

Dunbar J, Ticknor LO, Kuske CR (2001) Phylogenetic specificity and reproducibility and new method for analysis of terminal restriction fragment profiles of 16S rRNA genes from bacterial communities. Appl Environ Microbiol 67: 190-197

Egert M, Friedrich MW (2003) Formation of pseudo-terminal restriction fragments, a PCR-related bias affecting terminal restriction fragment length polymorphism analysis of microbial community structure. Appl Environ Microbiol 69:2555-2562

Engebretson JJ, Moyer CL (2003) Fidelity of select restriction endonucleases in determining microbial diversity by terminal-restriction fragment length polymorphism. Appl Environ Microbiol 69:4823-4829

Finlay BJ, Maberly SC, Cooper JI (1997) Microbial diversity and ecosystem function. Oikos 80:209-213

Fuhrman JA, Hewson I, Schwalbach MS, Steele JA, Brown MV, Naeem S (2006) Annually reoccurring bacterial communities are predictable from ocean conditions. Proc Natl Acad Sci USA 103:13104-13109

Hammer Ø, Harper DAT, Ryan PD (2001) PAST: paleontological statistics software package for education and data analysis. Palaeontol Electr 4:9, available at: palaeoelectronica.org/2001_1/past/issue1_01.htm

Head IM, Saunders JR, Pickup RW (1998) Microbial evolution, diversity, and ecology: a decade of ribosomal RNA analysis of uncultivated microorganisms. Microb Ecol 35:1-21

> Jardillier L, Basset M, Domaizon I, Belan A, Amblard C, Richardot M, Debroas D (2004) Bottom-up and top-down control of bacterial community composition in the euphotic zone of a reservoir. Aquat Microb Ecol 35: $259-273$

Kan JJ, Crump BC, Wang K, Chen F (2006) Bacterioplankton community in Chesapeake Bay: predictable or random assemblages. Limnol Oceanogr 51:2157-2169

Lee DH, Zo YG, Kim SJ (1996) Nonradioactive method to study genetic profiles of natural bacterial communities by PCR-single-strand-conformation polymorphism. Appl Environ Microbiol 62:3112-3120

Legendre P, Legendre L (1998) Numerical ecology, 2nd English edn., Elsevier, Amsterdam

Lehours AC, Bardot C, Thenot A, Debroas D, Fonty G (2005) Anaerobic microbial communities in Lake Pavin: a unique meromictic lake in France. Appl Environ Microbiol 71: $7389-7400$

> Loisel P, Harmand J, Zemb O, Latrille E, Lobry C, Delgenès J, Godon J (2006) Denaturing gradient gel electrophoresis (DGGE) and single strand conformation polymorphism (SSCP) molecular fingerprintings revisited by simulation and used as a tool to measure microbial diversity. Environ Microbiol 8:720-731

Lüdemann H, Arth I, Liesack W (2000) Spatial changes in the bacterial community structure along a vertical oxygen gradient in flooded paddy soil cores. Appl Environ Microbiol 66:754-762

Mantel N (1967) The detection of disease clustering and a generalized regression approach. Cancer Res 27:209-220

Martiny AC, Jørgensen TM, Albrechtesen HJ, Arvin E, Molin S (2003) Long-term succession of structure and diversity of a biofilm formed in a model drinking water distribution system. Appl Environ Microbiol 69:6899-6907

> Michard G, Sarazin G, Jézéquel D, Albéric P, Ogier S (2001) Annual budget of chemical elements in a eutrophic lake, Aydat lake (Puy-de-Dôme), France. Hydrobiologia 459: $27-46$

> Moeseneder MM, Arrieta JM, Muyzer G, Winter C, Herndl GJ (1999) Optimization of terminal-restriction fragment length polymorphism analysis for complex marine bacterioplankton communities and comparison with denaturing gradient gel electrophoresis. Appl Environ Microbiol 65: $3518-3525$

Muyzer G, Smalla K (1998) Application of denaturing gradient gel electrophoresis (DGGE) and temperature gradient gel electrophoresis (TGGE) in microbial ecology. Antonie Leeuwenhoek 73:127-141

Muyzer G, de Waal EC, Uitterlinden AG (1993) Profiling of complex microbial populations by denaturing gradient gel electrophoresis analysis of polymerase chain reactionamplified genes coding for 16S rRNA. Appl Environ Microbiol 59:695-700

Ogier S (1999) Diagenèse précoce en domaine lacustre: étude des composés minéraux et organiques des sédiments récents du Lac d'Aydat (Puy de Dôme, France). PhD thesis, Université d'Orléans, Orléans

- Osborn MA, Moore ERB, Timmis KN (2000) An evaluation of terminal-restriction fragment length polymorphism ( $\mathrm{T}$ RFLP) analysis to the study of microbial community structure and dynamics. Environ Microbiol 2:39-50

Pace NR (1997) A molecular view of microbial diversity and the biosphere. Science 276:734-740

> Pedrós-Alió C (2006) Marine microbial diversity: Can it be determined? Trends Microbiol 14:257-263

Risatti JB, Capman WC, Stahl DA (1994) Community structure of a microbial mat: the phylogenetic dimension. Proc Natl Acad Sci USA 91:10173-10177

Sigler WV, Zeyer J (2004) Colony-forming analysis of bacterial community succession in deglaciated soils indi- 
cates pioneer stress-tolerant opportunists. Microb Ecol 48: 316-323

Smith B, Wilson JB (1996) A consumers's guide to evenness indices. Oikos 76:70-82

Sneath PH, Sokal RR (1973) Numerical taxonomy. WH Freeman, San Francisco, CA

Suzuki MT, Giovannoni SJ (1996) Bias caused by template annealing in the amplification of mixtures of 16S rRNA genes by PCR. Appl Environ Microbiol 62:625-630

Vetriani C, Tran HV, Kerkhof LJ (2003) Fingerprint microbial assemblages from the oxic/anoxic chemocline of the Black sea. Appl Environ Microbiol 69:6481-6488

Editorial responsibility: Karel Šimek, Ceske Budejovice, Czech Republic
Ward JH (1963) Hierarchical Grouping to optimize an objective function. J Am Stat Assoc 58:236-244

Weinbauer MG, Holfe MG (1998) Signifiance of viral lysis and flagellates grazing as factors controlling bacterioplankton production in a eutrophic lake. Appl Environ Microbiol 64:431-438

Weisburg WG, Barns SM, Pelletier DA, Lane DJ (1991) 16S ribosomal DNA amplification for phylogenetic study. J Bacteriol 173:697-703

Zhou J, Xia B, Treves DS, Wu LY and others (2002) Spatial and resource factors influencing high microbial diversity in soil. Appl Environ Microbiol 68:326-334

Submitted: May 19, 2008; Accepted: October 16, 2008

Proofs received from author(s): January 20, 2009 